\title{
Osiedla grodzone w Toruniu i ich postrzeganie wśród mieszkańców miasta
}

Anna Łątkowska

Toruń

Znaczna część miast polskich w ciągu ostatnich lat dynamicznie się rozwija. Współcześni socjologowie, geografowie społeczni i urbaniści twierdzą, iż częściej mamy do czynienia z pojawiającymi się w miastach zamkniętymi osiedlami mieszkaniowymi, mającymi wpływ na fragmentaryzację przestrzeni, prowadząc do tzw. gettoizacji, która jest jednym z najczęściej omawianych problemów współczesnych miast. Osiedla te często postrzegane są jako te, które mają zapewnić poczucie bezpieczeństwa oraz pozbycie się strachu przed przestępczością ${ }^{1}$ Osiedla za ogrodzeniem mają również wydźwięk społeczny. Chętnie odgradzamy się od „gorszego świata”, chcąc zapewnić sobie jak najdogodniejsze warunki do codziennego życia - pozbawione obcych, nieproszonych gości.

Celem niniejszego artykułu jest identyfikacja osiedli grodzonych i analiza ich rozmieszczenia oraz sposób postrzegania tego typu osiedli wśród mieszkańców miasta. Zakres przestrzenny pracy obejmuje teren miasta Torunia $\mathrm{w}$ podziale na dwadzieścia jednostek administracyjnych. Przedstawiono stan osiedli grodzonych ze stycznia 2017 r., odnosząc się jednocześnie do początków ich powstawania, tj. lat 90. dwu-

${ }^{1}$ M. Lewicka, K. Zaborska, Osiedla zamknięte - czy istnieje alternatywa?, Kolokwia Psychologiczne, 2007, nr 16, s. 135-152. 


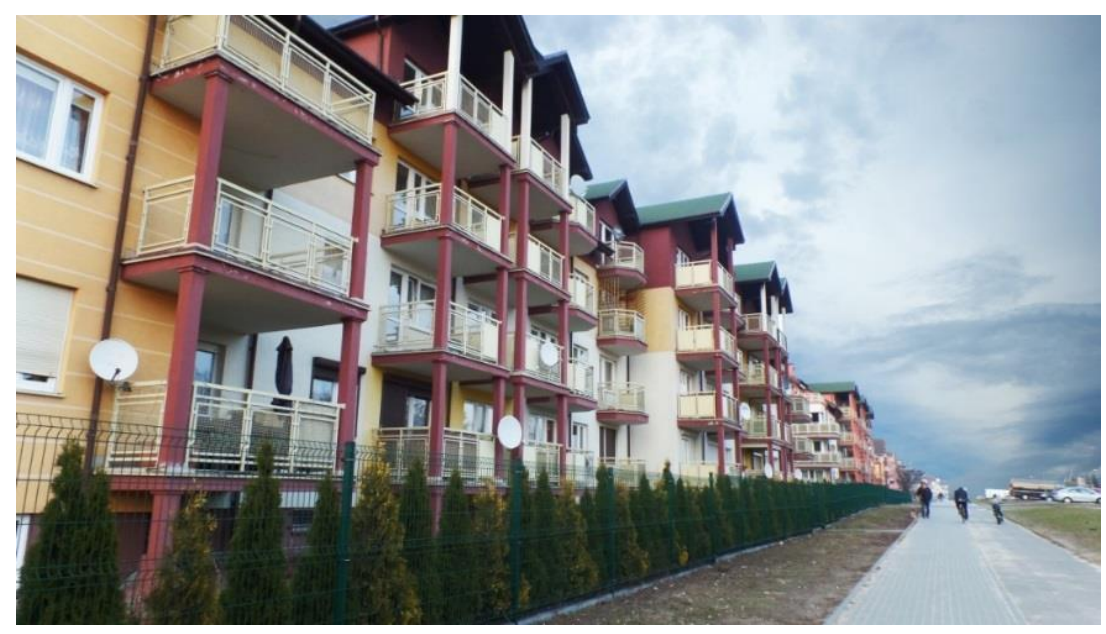

Fot. 1. Osiedle grodzone przy ul. Zbożowej na Wrzosach (fot. A. Łątkowska, 2017)

dziestego wieku, kiedy to zaczęły powstawać pierwsze osiedla zamknięte na terenie dużych miast Polski²

\section{Powstanie i rozwój osiedli grodzonych w Polsce}

Pojawienie się osiedli grodzonych w Polsce wiązać można z chęcią odcięcia się od socjalistycznej wizji miasta, która towarzyszyła krajowi przez długi czas. Jako cechę takiego miasta wyróżnić można było to, iż mieszkańcy często osiedlani byli niezależnie od swych preferen$\mathrm{cji}^{3}$. Niejednokrotnie osiedla mieszkaniowe budowane były wokół miejsca pracy, co znacznie utrudniało powstawanie społeczności lokalnych. Co więcej, powstawały również tzw. jednozawodowe osiedla, które były związane z jednym zakładem przemysłowym. Jako kolejne cechy miast socjalistycznych Węcławowicz wymienia monotonną architekturę

\footnotetext{
${ }^{2}$ J. Gądecki, Za murami: Osiedla grodzone w Polsce - analiza dyskursu, Wrocław 2009.

${ }^{3}$ G. Węcławowicz, Miasto polskie w transformacji - ksztaltowanie się miasta postsocjalistycznego, [w:] XI Konwersatorium Wiedzy o Mieście, red. J. Kaczmarek, Łódź 1999.
} 
oraz jednostajność w projektowaniu osiedli mieszkaniowych. Co więcej, obszary mieszkaniowe były w tamtym okresie ogromnymi kompleksami mieszkaniowymi, znajdującymi się na otwartej przestrzeni wśród zabudowy miejskiej, która nierzadko charakteryzowała się nieestetycznym wyglądem. Miasta socjalistyczne charakteryzowały się również monotonnym wyglądem ulic oraz przede wszystkim mało zróżnicowanym typem dostępnych mieszkań ${ }^{4}$. W krajach postkomunistycznych, do których zalicza się Polskę, osiedla zamknięte to objaw reakcji na wyżej wymienione elementy komunistycznej przeszłości, kiedy społeczeństwo było pozbawione prawa do prywatności; obecnie przejawia się to w przesadnym dążeniu do grodzenia miejsc zamieszkania.

Tendencja do wyboru osiedli grodzonych wśród polskiej klasy średniej to również wyraz niechęci do zamieszkania w dzielnicach zabudowanych w latach 70. i 80. dwudziestego wieku' ${ }^{5}$. Odnotowuje się tzw. „segregację przestrzenną grup społecznych"6, która wyraża się lepszą sytuacją osób zamożniejszych, które mają większy wybór miejsca, w którym zamieszkają. Nierzadko zdarza się, że wybór mieszkania kończy się na grodzonym osiedlu. Co więcej, stwierdzono, iż takie decyzje są często wyrazem potrzeby wyróżniania mieszkańców w stosunku do innych, uboższych klas społecznych ${ }^{7}$. Współczesne propozycje deweloperów coraz częściej dążą więc do spełnienia wymagań potencjalnego klienta, który poszukuje miejsca zamieszkania, przy czym jako najważniejsze kryterium wskazuje bezpieczeństwo oraz wysoki standard zabudowy.

Pierwsze osiedla zamknięte w Warszawie zaczęły się pojawiać pod koniec lat 90. dwudziestego wieku ${ }^{8}$, co miało bezpośredni związek

${ }^{4}$ J. Kaczmarek, Świat życia czlowieka w mieście postsocjalistycznym. Zarys koncepcji badawczej, [w:] XIII Konwersatorium Wiedzy o Mieście, red. I. Jażdżewska, Łódź 2000.

${ }^{5}$ D. Owczarek, Zamknięte osiedla, czyli dylemat wspótczesnych polskich miast. Badanie porównawcze mieszkańców zamkniętych i otwartych osiedli $w$ Warszawie, Przegląd Socjologiczny, 2011, nr 60, s. 367-394.

${ }^{6} \mathrm{Z}$. Rykiel, Przemiany przestrzeni spolecznej polskiego miasta postsocjalistycznego, [w:] XIII Konwersatorium Wiedzy o Mieście.

${ }^{7}$ A. Gąsior-Niemiec, G. Glasze, R. Putz, D. Sinz, Grodzenie miasta: casus Warszawy, Studia Regionalne i Lokalne, 2007, $\mathrm{nr} 4$ (30).

${ }^{8}$ J. Gądecki, Za murami: Osiedla grodzone w Polsce. 
z rozwojem wolnego rynku nieruchomości w Polsce. Jako okres największego rozprzestrzenienia liczby tego typu osiedli można wskazać lata 2001-2008. W stolicy osiągnęła wówczas już ponad $400^{9}$. Warszawa pod tym względem zdystansowała całą Wielką Brytanię, a równa się z Buenos-Aires - miastem większym o 7 milionów mieszkańców ${ }^{10}$.

W Europie Zachodniej mamy do czynienia ze znacznie mniejszą popularnością tego typu osiedli - w Niemczech istnieje tylko jedno na granicy z Poczdamem, natomiast we Francji odnotowano 183 strzeżone osiedla, przy czym tylko 72 z nich były grodzone (Jałowiecki, 2007).

Coraz bardziej nasilające się zjawisko powstawania osiedli grodzonych w Polsce przykuwa uwagę dziennikarzy i socjologów, przez co w prasie coraz częściej mamy do czynienia $\mathrm{z}$ opracowaniami na ten temat. Rok 1989 jest określany jako przełom, od kiedy Polacy mogą korzystać z wolności. W polskim społeczeństwie zaczęto dostrzegać postawy indywidualistyczne ${ }^{11}$. Przejawiają się one $\mathrm{w}$ coraz większej nieufności względem drugiego człowieka, co powoduje osłabienie relacji międzyludzkich. Ludzie przywiązują coraz większą wagę nie do dobra wspólnego, lecz do zapewnienia sobie bezpieczeństwa oraz godnego życia. Chętnie zamykają się w gronie osób do nich podobnych, wykluczając jednocześnie tych o innym statusie społecznym. Można to wiązać $\mathrm{z}$ obserwowanym w ostatnim czasie powstawaniem wspomnianej już wcześniej tzw. polskiej klasy średniej ${ }^{12}$. Wiele ogólnodostępnych miejsc zostało utraconych na zawsze przez utworzenie osiedli o ograniczonym dostępie, co świadczy o zaburzeniu ładu przestrzennego w polskich miastach ${ }^{13}$.

\footnotetext{
${ }^{9}$ M. Lewicka, K. Zaborska, Osiedla zamknięte - czy istnieje alternatywa? s. 135-152.

${ }^{10}$ M. Obarska, Zamknięte osiedla - kulturowy i socjologiczny fenomen getta, Kultura Miasta - Miasto w Kulturze, 2008, nr 1, s. 36-42.

${ }^{11}$ L. Michałowski, Granice bezpieczeństwa, czyli krótka historia pewnego bloku, [w:] B. Jałowiecki, W. Łukowski, Gettoizacja polskiej przestrzeni miejskiej, Warszawa 2007.

${ }^{12}$ B. Jałowiecki, M. Szczepański, Miasto i przestrzeń w perspektywie socjologicznej, Warszawa 2006.

${ }^{13}$ M. Dymnicka, Osiedla za brama a ciagłość kulturowa i spoleczna w ksztaltowaniu przestrzeni miejskiej, [w:] B. Jałowiecki, W. Łukowski, Gettoizacja polskiej przestrzeni miejskiej.
} 


\section{Liczebność i rozmieszczenie osiedli grodzonych w przestrzeni miasta Torunia}

Mając na celu przedstawienie aktualnej sytuacji osiedli grodzonych w Toruniu autorka przeprowadziła kwerendę terenową, na podstawie której zebrano informacje na temat istniejących w przestrzeni miasta osiedli zamkniętych. W tabeli 1 przedstawiono nazwy jednostek urbanistycznych, w obrębie których znajdują się omawiane osiedla, zajmowaną przez nie powierzchnię wyrażoną w metrach kwadratowych oraz jej udział w ogólnej powierzchni jednostki urbanistycznej. W przypadku każdego z osiedli przebadano, czy na jego terenie oprócz ogrodzenia i monitoringu występują: plac zabaw, punkty usługowo-handlowe, parking oraz czy wynajęte są służby ochrony. Dzięki temu możliwe było dogłębne przebadanie stanu i struktury osiedli grodzonych w Toruniu.

Tabela 1. Osiedla grodzone w jednostkach urbanistycznych Torunia

\begin{tabular}{|r|l|c|c|}
\hline Lp. & \multicolumn{1}{|c|}{$\begin{array}{c}\text { Nazwa jednostki } \\
\text { urbanistycznej }\end{array}$} & $\begin{array}{c}\text { Łączna } \\
\text { powierzchnia } \\
\text { osiedli } \\
\text { grodzonych } \\
\left(\mathrm{m}^{2}\right)\end{array}$ & $\begin{array}{c}\text { Udział powierzchni } \\
\text { osiedli grodzonych } \\
\text { w ogólnej powierzchni } \\
\text { jednostki urbanistycznej } \\
(\%)\end{array}$ \\
\hline 1 & Barbarka & - & - \\
\hline 2 & Bielany & 37933 & 1,65 \\
\hline 3 & Bielawy & 23404 & 1,16 \\
\hline 4 & Bydgoskie Przedmieście & 78898 & 1,68 \\
\hline 5 & Chełmińskie Przedmieście & 62015 & 1,48 \\
\hline 6 & Czerniewice & - & - \\
\hline 7 & Grębocin Nad Strugą & 35995 & 1,43 \\
\hline 8 & Grębocin Przy Lesie & - & - \\
\hline 9 & Jakubskie Przedmieście & 144742 & 0,45 \\
\hline 10 & Kaszczorek & 30852 & - \\
\hline 11 & Katarzynka & - & - \\
\hline 12 & Mokre Przedmieście & - & 0,31 \\
\hline 13 & Na Skarpie & 17672 & - \\
\hline 14 & Podgórz & 27791 & - \\
\hline 15 & Rubinkowo & -24 \\
\hline
\end{tabular}




\begin{tabular}{|r|l|c|c|}
\hline 16 & Rudak & - & - \\
\hline 17 & Stare Miasto & - & - \\
\hline 18 & Starotoruńskie Przedmieście & - & - \\
\hline 19 & Stawki & 68980 & 0,91 \\
\hline 20 & Wrzosy & 56309 & 0,55 \\
\hline \multicolumn{2}{|l|}{ Razem } & 584591 & 0,51 \\
\hline
\end{tabular}

Źródło: Opracowanie własne.

Tabela 1 ukazuje łączną powierzchnię osiedli grodzonych w poszczególnych jednostkach urbanistycznych. Największą łączną powierzchnię osiedli grodzonych w ogólnej powierzchni jednostki odnotowano na Jakubskim Przedmieściu $\left(144742 \mathrm{~m}^{2}\right)$, Bydgoskim Przedmieściu $\left(78898 \mathrm{~m}^{2}\right)$ oraz na Stawkach $\left(68980 \mathrm{~m}^{2}\right)$. Można to odnieść do głównych motywów powstawania osiedli grodzonych - dążenia do poczucia bezpieczeństwa oraz prestiżu ${ }^{14}$. Jakubskie Przedmieście oraz Stawki są jednostkami urbanistycznymi, które cieszą się dobrą renomą wśród mieszkańców Torunia. Można stwierdzić, że są pożądanymi miejscami potencjalnego zamieszkania. Bydgoskie Przedmieście jest natomiast kojarzone $\mathrm{z}$ wysoką przestępczością, przez co osiedla zamknięte mogą być elementem ochrony przed niepożądanymi „gośćmi”. W dziewięciu jednostkach urbanistycznych nie zaobserwowano występowania osiedli grodzonych spełniających obrane kryteria.

Bardzo istotne dla niniejszej pracy było odniesienie powierzchni zajmowanej przez osiedla grodzone do powierzchni całego miasta. Otrzymane wyniki wskazują, iż zamknięte kompleksy mieszkaniowe w liczbie 51 osiedli zajmują w przestrzeni Torunia $584591 \mathrm{~m}^{2}$, co stanowi zaledwie $0,51 \%$ jego całej powierzchni oraz 1,18\% wszystkich gruntów zabudowanych i zurbanizowanych w mieście. Warto w tym miejscu zaznaczyć również, że osiedla zamknięte zajmują niecałe 5\% wszystkich terenów zajętych przez zabudowę mieszkaniową na terenie Torunia. Taki stan rzeczy niewątpliwie można uznać za zjawisko pozytywne.

${ }^{14}$ J. Gądecki, Za murami: Krytyczna analiza dyskursu na temat osiedli typu gated communities w Polsce, [w:] B. Jałowiecki, W. Łukowski, Gettoizacja polskiej przestrzeni miejskiej. 


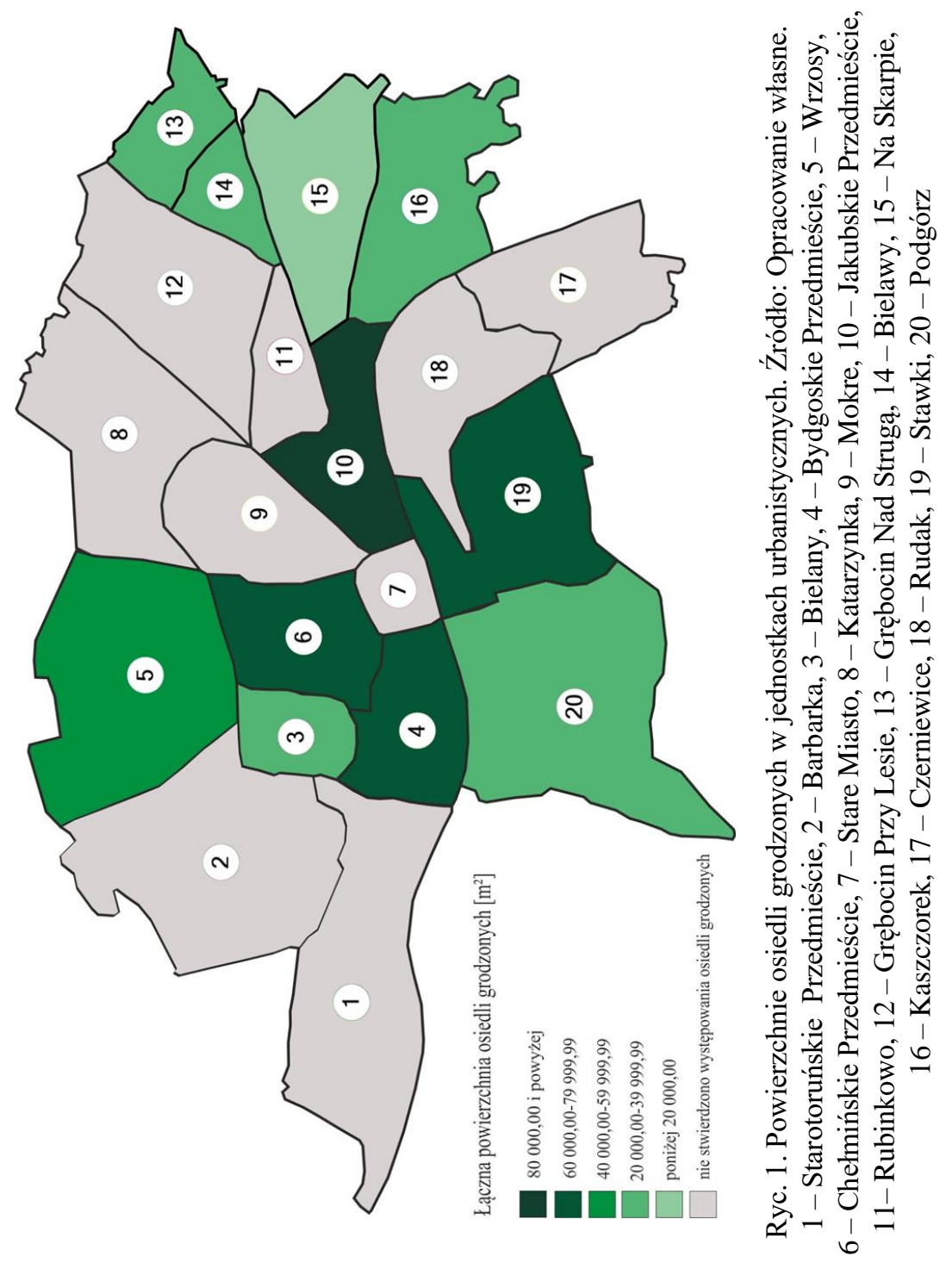



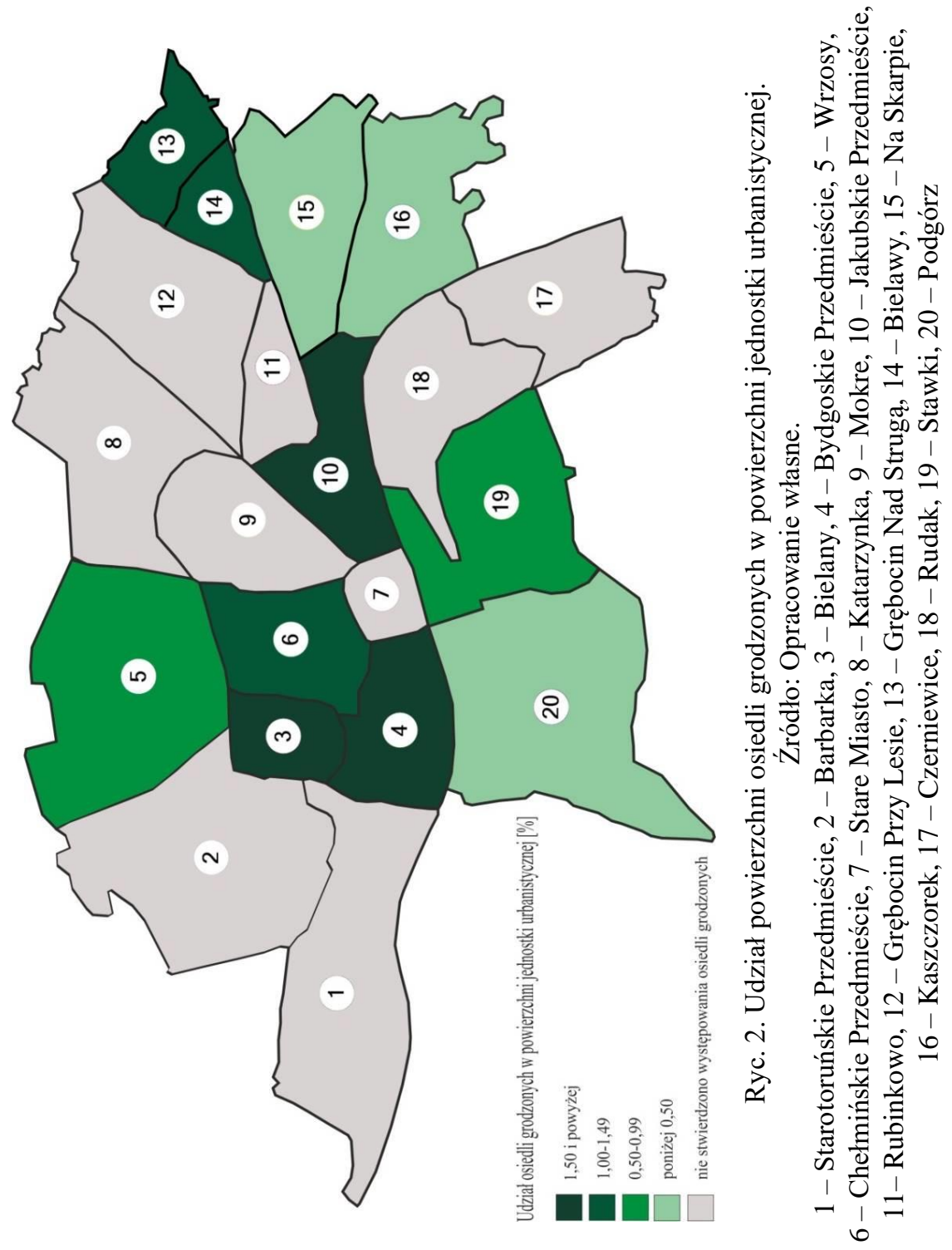


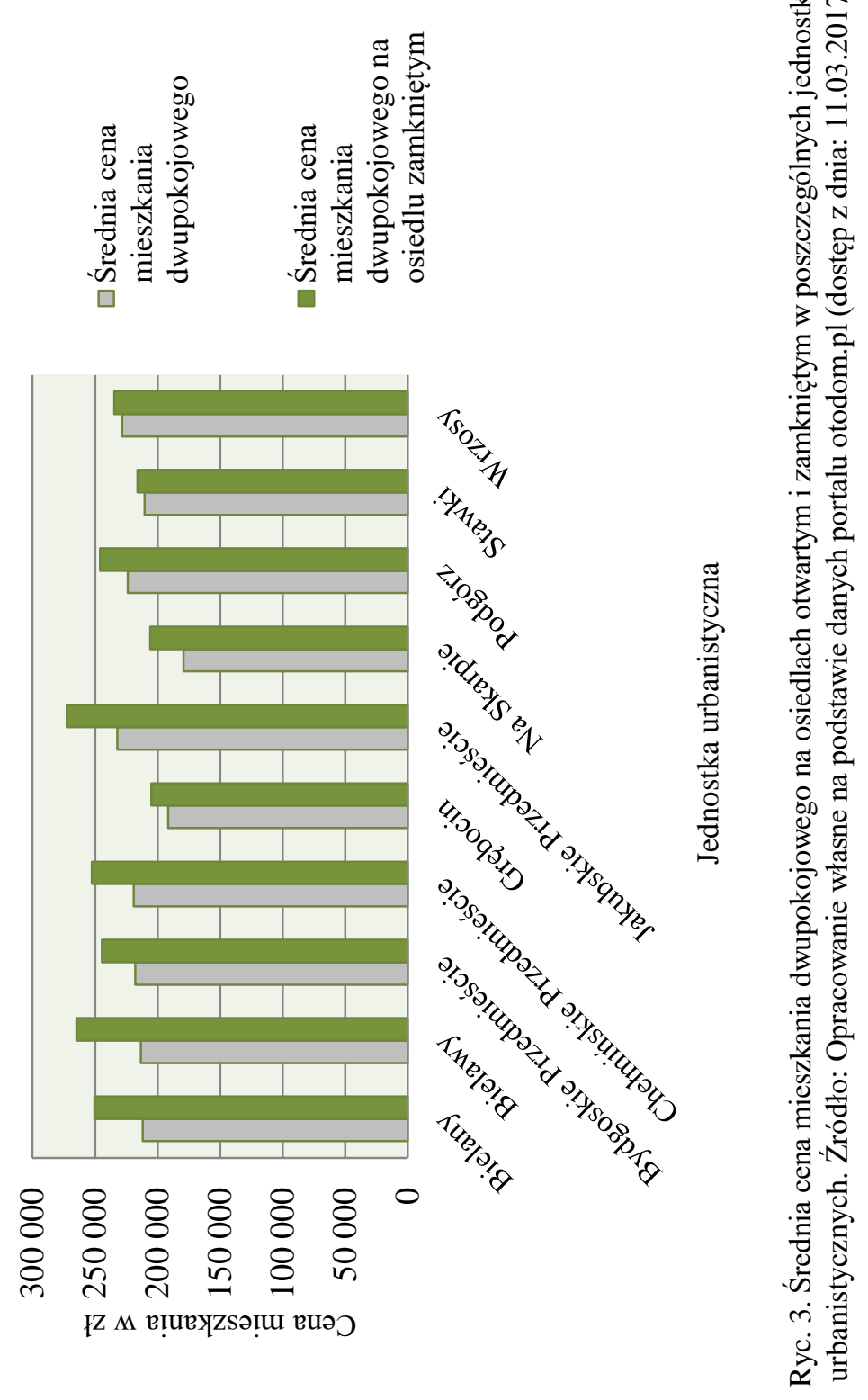




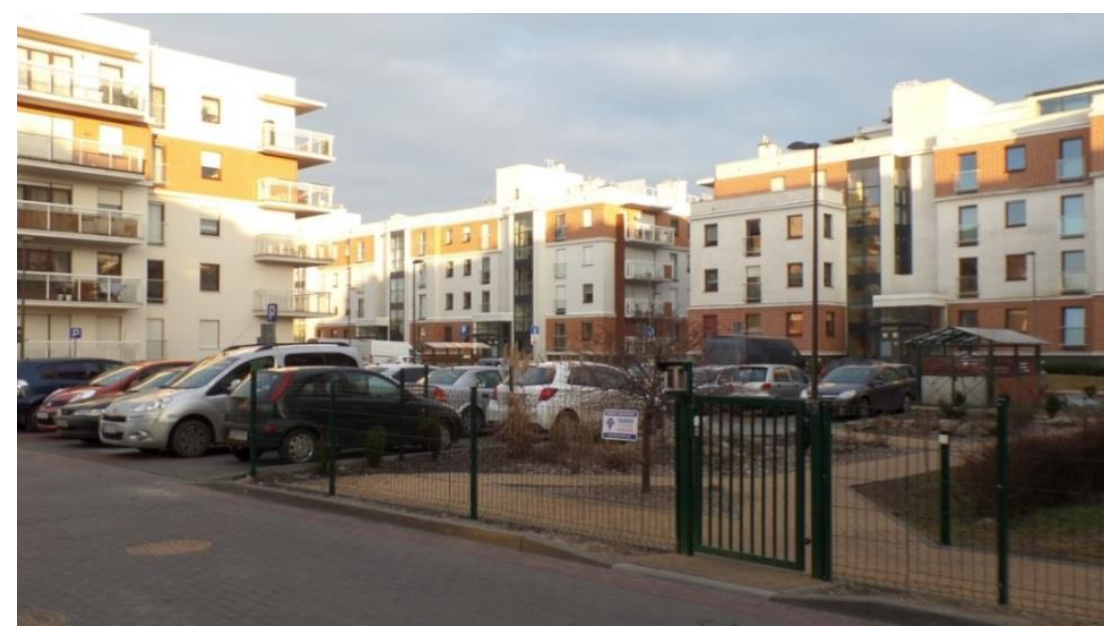

Fot. 2. Osiedle „Winnica” przy ul. Szosa Lubicka na Jakubskim Przedmieściu (fot. A. Łątkowska, 2017)

$\mathrm{Na}$ podstawie wykonanych obliczeń (ryc. 2) zaobserwowano, iż najwyższy udział $\mathrm{w}$ ogólnej powierzchni jednostki stanowią osiedla grodzone znajdujące się na Jakubskim Przedmieściu. Jest to wartość przekraczająca 3,00\%. Drugie miejsce zajmuje Bydgoskie Przedmieście z wartością 1,68\%, a trzecie Bielany z udziałem 1,65\%.

W celu wzbogacenia otrzymanych wyników autorka przeanalizowała rozkład cen mieszkań dwupokojowych w Toruniu w zależności od ich umiejscowienia (ryc. 3). Otrzymane wyniki wykazują, iż mieszkania znajdujące się na terenie osiedli zamkniętych są droższe średnio o $14 \%$ w porównaniu z mieszkaniami na osiedlach ogólnodostępnych. Średnia różnica w wyniosła 26485 zł.

\section{Postrzeganie osiedli grodzonych w Toruniu przez lokalną społeczność - analiza wyników wywiadów swobodnych}

Wywiady jakościowe pozwoliły na poznanie opinii na temat osiedli grodzonych zarówno ze strony ich mieszkańców, jak i osób mieszkających na co dzień na osiedlach ogólnodostępnych. Przeprowadzono pięt- 
naście wywiadów, z czego dziesięć wśród mieszkańców osiedli grodzonych, a pięć wśród osób zamieszkałych na osiedlu otwartym. Wiek ankietowanych wahał się od 24 do 55 lat. Badanie było w dużym stopniu utrudnione ze względu na ograniczony dostęp do osób mieszkających na osiedlach grodzonych. Niezbędne okazało się pozyskanie gatekeepera, który w znaczący sposób ułatwił przeprowadzenie badań wśród mieszkańców. Wywiad swobodny to rozmowa, która ma na celu pozyskanie jak najwięcej informacji od respondenta. Bardzo ważnym aspektem badania było uzyskanie wiadomości odnośnie do bezpieczeństwa, estetyki, sąsiedztwa oraz infrastruktury na osiedlach mieszkaniowych. Nadzwyczaj istotne było również pytanie respondentów $z$ osiedli otwartych o wady oraz zalety mieszkania na osiedlach grodzonych. Autorka w ramach badań skupiła się również na pojęciu gettoizacji przestrzeni miejskiej i zapytała o jego znajomość wśród odpowiadających.

$\mathrm{Na}$ wstępie warto zaznaczyć, iż mieszkańcy osiedli grodzonych biorący udział w badaniu to w większości osoby $\mathrm{z}$ wyższym wykształceniem. Jeśli chodzi o wykonywany przez respondentów zawód zaistniała pełna różnorodność. Wśród pytanych znaleźli się m.in.: informatyk, urzędnik, instruktor fitness, przedstawiciel handlowy, menadżer restauracji. Jak zauważa M. Szczepański ${ }^{15}$, osoby zamieszkujące osiedla zamknięte prowadzą podobny tryb życia, a rytm dnia u wszystkich jest zbliżony, podobnie spędzają dni wolne od pracy. Zazwyczaj mieszkają w pojedynkę bądź razem ze współlokatorem. Należy również podkreślić, iż respondenci są właścicielami mieszkań, rzadziej je wynajmują lub mieszkają $\mathrm{w}$ nich wraz $\mathrm{z}$ rodzicami. W większości przypadków osoby mieszkające na osiedlach zamkniętych wcześniej zamieszkiwały osiedla ogólnodostępne.

Otrzymane wyniki wykazały, że mieszkańcy osiedli grodzonych w większości czują się bezpiecznie w swoich miejscach zamieszkania. Jedna $\mathrm{z}$ respondentek mówi:

${ }^{15}$ M. Szczepański, Bramy raju i miejsca przeklęte? Socjolog miasta wobec różnych form wykluczenia społecznego na Górnym Śląsu, Przegląd Socjologiczny, 2008, nr 57, s. 177-199. 
Na pewno czuję się bezpieczniej niż na nieogrodzonym, mniej martwię się, gdy samochód zostawię na dworze - wiem, że w pewnym sensie jest zabezpieczony przed niechcianymi osobami.

Warto jednak zwrócić uwagę, iż nie każdy z odpowiadających twierdzi tak samo:

Wydaje mi się, że bezpieczeństwo jest wyższe niż na standardowym, otwartym osiedlu. Jednak nie uważam, że tylko samo grodzenie podwyższa poziom bezpieczeństwa. Istotny jest również sprawny monitoring - w mojej sieci kablowej, dzięki inicjatywie spółdzielni mieszkaniowej, istnieje możliwość podglądu obrazu z kamer na osiedlu. Podczas gdy mieszkańcy zauważą coś niepokojącego, mogą natychmiast powiadomić odpowiednie służby. W kwestii ogrodzeń i dostępu do terenu osiedla mam pewne zastrzeżenia - czasem są to niesprawnie działające elektromagnesy w furtkach, co umożliwia wtargnięcie na teren osiedla osobom postronnym. Dlatego nie uważam, aby był to główny wyznacznik bezpieczeństwa - jest to co najwyżej drobne utrudnienie dla potencjalnych złodziei czy wandali.

Kolejny z pytanych odpowiada:

Moje zdanie jednak jest takie, że jeśli ktoś będzie chciał, to i tak na takie osiedle się dostanie. Poczeka, poobserwuje i wejdzie. Płot nie daje bezpieczeństwa, może ochraniane osiedle sprawia, że ludzie czują się bezpieczniej. Ale samo ogrodzenie na pewno go nie zapewnia.

Warto w tym miejscu odnieść się także do estetyki oraz infrastruktury osiedli zamkniętych. Można stwierdzić, że przez większość mieszkańców są one dobrze oceniane.

Tutaj nie mam żadnych zastrzeżeń. Mamy specjalną ekipę sprzątającą, która dba o czystość klatek schodowych oraz chodników czy terenów zielonych. Porównując to $\mathrm{z}$ moim poprzednim doświadczeniem $\mathrm{z}$ osiedlem otwartym, widzę znaczącą różnicę - na plus. Estetykę i czystość oceniam więc bardzo dobrze.

Inny z pytanych stwierdza:

Infrastruktura na moim osiedlu jest bardzo bogata, więc oceniam ją bardzo dobrze, w pełni zaspokaja ona moje potrzeby. Na terenie osiedla znajdują się miejsca do siedzenia, kosze na śmieci, plac zabaw dla dzieci, górka saneczkowa, ciekawie zagospodarowane tereny zieleni.

Podsumowując, na podstawie wykonanych badań można stwierdzić, iż osoby zamieszkujące osiedla grodzone są zadowolone ze swojego miejsca zamieszkania, nierzadko podkreślają jednak, iż ogrodze- 
nie nie gwarantuje stuprocentowego bezpieczeństwa. Co więcej, ważne jest to, że wysoko oceniają one estetykę oraz infrastrukturę osiedli, jednak czasem podkreślają niedostatek zieleni na ich terenie. W znacznie gorszym świetle przedstawiają się relacje sąsiedzkie, które na zamkniętych osiedlach są bardzo słabe. Mieszkańcy nie znają się nawzajem, nierzadko ich kontakt kończy się na „dzień dobry” wymienionym na klatce schodowej. Fakt ten potwierdzają chociażby słowa jednego z mieszkańców:

Szczerze, nie znam za bardzo swoich sąsiadów. Mijamy się, nierzadko bez słowa. Kojarzę ludzi z osiedla, ale chyba z żadnym nie zamieniłem więcej niż kilku zdań. Jestem dość zapracowany, a najbliżsi przyjaciele mieszkają w innych częściach miasta lub w mojej rodzinnej miejscowości.

Bardzo ciekawie na ten temat wypowiada się również były mieszkaniec osiedla otwartego:

Mimo że mieszkamy w dużych skupiskach, to niespecjalnie nawiązujemy bliższe kontakty. Często nie znamy tak dobrze sąsiadów, jak to miało miejsce jeszcze kilka lat wstecz. Teraz często skład mieszkańców się zmienia, mieszkania są wynajmowane i niekiedy trudno o stałą relację z lokatorami. Jeśli chodzi o mnie, znam najbliższych sąsiadów $\mathrm{z}$ naprzeciwka oraz znajomych „Z widzenia”, których spotykam na co dzień. Wychowywałem się na osiedlu otwartym - przyznaję, że relacje były bliższe i bywało, że sąsiedzi odwiedzali nas w domu lub to my byliśmy w odwiedzinach.

Otrzymane przez autorkę wyniki są zbliżone do tych przeprowadzonych w Warszawie przez M. Lewicką ${ }^{16}$, która wykazała, iż poczucie bezpieczeństwa na osiedlach grodzonych jest większe, jednak mieszkańcy gorzej oceniają swoje relacje z sąsiadami. Również M. Szczepański (2008) podkreśla, że na zamożnych, zamkniętych osiedlach mamy do czynienia z ekskluzją wewnętrzną, która wyrażana jest świadomym wycofaniem się z życia społeczności, motywowanym próbą podkreślenia swojego statusu społecznego, ale także odseparowania się od tych pozostających za bramą. Co więcej, autor dodaje, że spostrzega się zacierającą się w dzisiejszych czasach wspólnotowość, wskutek czego powstają obszary zamieszkiwane przez wiele osób w żaden sposób ze sobą niepowiązanych.

\footnotetext{
${ }^{16}$ M. Lewicka, K. Zaborska, Osiedla zamknięte - czy istnieje alternatywa?, s. 135-152.
} 
Odnosząc się do wyników badań w osiedlach otwartych warto rozpocząć od odpowiedzi dotyczących zamiaru zamieszkania na osiedlach grodzonych. W znaczącej części respondenci wyrażali chęć do przeprowadzki na takie osiedle, jednak w dwóch przypadkach sytuacja była odwrotna. Jako zalety mieszkania na takim osiedlu najczęściej wymieniano większe bezpieczeństwo oraz brak obcych, niepożądanych osób w sąsiedztwie miejsca zamieszkania. Ponadto osiedla grodzone są kojarzone z większą estetyką, a także lepszym wyposażeniem. Mieszkańcy na osiedlach otwartych narzekają na zaniedbane klatki schodowe czy wymagające remontu chodniki. Nie podoba im się również stan zieleni wokół bloków:

Dojazd i chodniki wokół osiedla - nikt nie dba o to od lat, są krzywe, łatwo o potknięcie. Wejście do klatki schodowej również nie prezentuje się dobrze - dach jest zardzewiały, płotki wokół osiedla są stare i zardzewiałe. Przydałoby się też wymienić skrzynki pocztowe i pomalować wnętrze. Mało też terenów zielonych, a te drzewka, które są, znajdują się w opłakanym stanie.

$\mathrm{Na}$ osiedlach ogólnodostępnych znacznie lepszy jest kontakt z sąsiadami. Ludzie lepiej się znają, często się odwiedzają. Warto przytoczyć tutaj słowa jednej z mieszkanek osiedla otwartego:

Znam większość sąsiadów, którzy podobnie jak ja mieszkają tutaj od dawna. Nie ma problemów z zakłócaniem ciszy nocnej czy hałasem. Ostatnio jednak widoczna jest rotacja mieszkańców - dużo młodych wynajmuje mieszkanie.

W wywiadach zarówno pośród osób zamieszkujących osiedla otwarte, jak i zamknięte pojęcie gettoizacji nie jest dobrze znane. Tylko nieliczni znali to słowo bądź potrafili je wyjaśnić w sposób ogólny. Gettoizacja była wśród ankietowanych kojarzona $\mathrm{z}$ odosobnieniem, z zamknięciem na innych. Jedna z osób biorących udział w wywiadzie stwierdza:

Owszem, posiadam wiedzę na ten temat. I dostrzegam to zjawisko na obszarze swojej dzielnicy. Osiedle, na którym mieszkam, jest ogrodzone, co powoduje izolację od innych osiedli znajdujących się w sąsiedztwie. Praktycznie nie ma kontaktu z osobami mieszkającymi na osiedlach w sąsiedztwie.

Inny z odpowiadających mówi:

Terminu nie znam, ale mogę się domyślać, że chodzi właśnie o powstawanie takich osiedli jak moje. Na pewno gettoizacja to nic dobrego, przynajmniej nie kojarzy mi się najlepiej. 
Tabela 2. Podsumowanie wyników wywiadów swobodnych

\begin{tabular}{|c|c|c|}
\hline Badana cecha & $\begin{array}{c}\text { Mieszkańcy } \\
\text { osiedla zamkniętego }\end{array}$ & $\begin{array}{c}\text { Mieszkańcy } \\
\text { osiedla otwartego }\end{array}$ \\
\hline Bezpieczeństwo & $\begin{array}{c}\text { Dobra ocena ogólna, } \\
\text { przeważa jednak spo- } \\
\text { strzeżenie, iż samo posta- } \\
\text { wienie muru nie zapewnia } \\
\text { całkowitej ochrony przed } \\
\text { niebezpieczeństwami. }\end{array}$ & $\begin{array}{l}\text { Odnotowuje się liczne } \\
\text { przypadki naruszenia } \\
\text { spokoju mieszkańców. } \\
\text { Pojawiają się nieproszeni } \\
\text { goście, każdy może wejść } \\
\text { do klatki schodowej. }\end{array}$ \\
\hline $\begin{array}{l}\text { Kontakty } \\
\text { sąsiedzkie }\end{array}$ & $\begin{array}{l}\text { Mieszkańcy w większości } \\
\text { nie znają swych sąsiadów, } \\
\text { kontakty ograniczają się } \\
\text { często do zwrotów } \\
\text { grzecznościowych na } \\
\text { klatce schodowej. }\end{array}$ & $\begin{array}{l}\text { Mieszkańcy nierzadko } \\
\text { znają się od lat, odczuwają } \\
\text { więź z sąsiadami, odwie- } \\
\text { dzają się i chętnie poma- } \\
\text { gają sobie nawzajem. }\end{array}$ \\
\hline Estetyka osiedla & $\begin{array}{l}\text { Oceniana przez mieszkań- } \\
\text { ców wysoko. Doceniane } \\
\text { jest rozplanowanie osie- } \\
\text { dli, jednak nadal w wy- } \\
\text { wiadach pojawiał się } \\
\text { problem niedostatku zie- } \\
\text { leni. }\end{array}$ & $\begin{array}{c}\text { Zauważa się, że mieszkań- } \\
\text { cy osiedli otwartych nie są } \\
\text { zadowoleni z estetyki na } \\
\text { swoich osiedlach. Brakuje } \\
\text { im systematycznych re- } \\
\text { montów, zieleni, miejsc do } \\
\text { rekreacji. }\end{array}$ \\
\hline $\begin{array}{l}\text { Infrastruktura } \\
\text { na osiedlu }\end{array}$ & $\begin{array}{l}\text { Wystarczająca, nierzadko } \\
\text { na osiedlach występują } \\
\text { punkty usługowo- } \\
\text { handlowe dedykowane } \\
\text { mieszkańcom. Liczne } \\
\text { place zabaw, miejsca } \\
\text { odpoczynku są doceniane } \\
\text { przez mieszkańców. }\end{array}$ & $\begin{array}{c}\text { Mieszkańcy narzekają na } \\
\text { brak dedykowanych par- } \\
\text { kingów oraz na często } \\
\text { zdewastowane ławki i } \\
\text { place zabaw. }\end{array}$ \\
\hline $\begin{array}{c}\text { Znajomość } \\
\text { pojęcia } \\
\text { gettoizacji }\end{array}$ & $\begin{array}{c}\text { Podstawowa znajomość } \\
\text { pojęcia. }\end{array}$ & $\begin{array}{l}\text { W większości przypadków } \\
\text { brak znajomości pojęcia. }\end{array}$ \\
\hline
\end{tabular}

Źródło: Opracowanie własne na podstawie przeprowadzonych wywiadów jakościowych.

$\mathrm{Z}$ informacji zawartych $\mathrm{w}$ tabeli 2 wynika, że mieszkańcy osiedli zamkniętych wysoko cenią bezpieczeństwo w swych miejscach za- 
mieszkania, jednak podkreślają, iż ochrony przed potencjalnym przestępcą nie zapewni tylko fizyczna bariera w postaci płotu bądź muru, ale konieczne jest dodatkowe wynajęcie służb ochrony lub czynny monitoring. Ogólnie mieszkańcy zamkniętych zespołów mieszkaniowych dobrze oceniają estetykę oraz infrastrukturę osiedla, znacznie gorzej odnoszą się do kontaktów sąsiedzkich. Sytuacja wygląda inaczej na osiedlach ogólnodostępnych, gdzie więzi sąsiedzkie są mocniejsze. O wiele niżej natomiast mieszkańcy osiedli otwartych oceniają estetykę, bezpieczeństwo oraz infrastrukturę. Nierzadko wspominają o koniecznych remontach, a także niedostatku zieleni w ich miejscach zamieszkania. Warto również nadmienić, iż pojęcie gettoizacji jest obce większości badanych mieszkańców Torunia, jednak widoczna jest nieco większa znajomość tej definicji wśród mieszkańców osiedli grodzonych.

Podsumowując, wydaje się, iż osiedla grodzone na stałe wpisują się w obecny krajobraz polskich miast, w tym także Torunia.

Istotny jest fakt, iż władze Torunia zauważają problem fragmentaryzacji przestrzeni miejskiej, co wynika z tworzenia zamkniętych osiedli mieszkaniowych. W związku z tym w „Strategii Rozwoju Miasta Torunia do roku 2020" pojawił się wpis dotyczący ograniczenia rozwoju tego typu budownictwa oraz dążenia do powstawania nowych, bezpiecznych, lecz nieogrodzonych osiedli mieszkaniowych. Działania toruńskich władz są widoczne chociażby na toruńskim Jarze, gdzie powstają nowocześnie zaplanowane, nieogrodzone zespoły mieszkaniowe. Można jednak przypuszczać, że zamknięte osiedla grodzone nadal będą się cieszyć popularnością. Mimo licznych konsekwencji ich powstawania, w tym między innymi doprowadzania do fragmentaryzacji przestrzeni miast, wiele osób w celu podwyższenia bezpieczeństwa swego i swych rodzin chętnie zamieszkuje tego typu osiedla.

\section{Bibliografia}

Dymnicka M., Osiedla za brama a ciagłość kulturowa i społeczna w kształtowaniu przestrzeni miejskiej, [w:] B. Jałowiecki, W. Łukowski, Gettoizacja polskiej przestrzeni miejskiej, Warszawa 2007. 
Gądecki J., Za murami: Krytyczna analiza dyskursu na temat osiedli typu gated communities w Polsce, [w:] B. Jałowiecki, W. Łukowski, Gettoizacja polskiej przestrzeni miejskiej, Warszawa 2007.

Gądecki J., Za murami: Osiedla grodzone w Polsce - analiza dyskursu, Wrocław 2009.

Gąsior-Niemiec A., Glasze G., Putz R., Sinz D., Grodzenie miasta: casus Warszawy, Studia Regionalne i Lokalne, 2007, nr 4 (30).

Jałowiecki B., Szczepański M., Miasto i przestrzeń w perspektywie socjologicznej, Warszawa 2006.

Kaczmarek J., Świat życia człowieka $w$ mieście postsocjalistycznym. Zarys koncepcji badawczej, [w:] XIII Konwersatorium Wiedzy o Mieście, red. I. Jażdżewska, Łódź 2000.

Lewicka M., Zaborska K., Osiedla zamknięte - czy istnieje alternatywa?, Kolokwia Psychologiczne, 2007, nr 16, s. 135-152.

Michałowski L., Granice bezpieczeństwa, czyli krótka historia pewnego bloku, [w:] B. Jałowiecki, W. Łukowski, Gettoizacja polskiej przestrzeni miejskiej, Warszawa 2007.

Obarska M., Zamknięte osiedla - kulturowy i socjologiczny fenomen getta, Kultura Miasta - Miasto w Kulturze, 2008, nr 1, s. 36-42.

Owczarek D., Zamknięte osiedla, czyli dylemat wspótczesnych polskich miast. Badanie porównawcze mieszkańców zamkniętych $i$ otwartych osiedli $w$ Warszawie, Przegląd Socjologiczny, 2011, nr 60, s. 367-394.

Rykiel Z., Przemiany przestrzeni społecznej polskiego miasta postsocjalistycznego, [w:] XIII Konwersatorium Wiedzy o Mieście, red. I. Jażdżewska, Łódź 2000.

Szczepański M., Bramy raju i miejsca przeklęte? Socjolog miasta wobec różnych form wykluczenia społecznego na Górnym Śląsku, Przegląd Socjologiczny, 2008, nr 57, s. 177-199.

Węcławowicz G., Miasto polskie w transformacji - kształtowanie się miasta postsocjalistycznego, [w:] XI Konwersatorium Wiedzy o Mieście, red. J. Kaczmarek, Łódź 1999. 